\title{
Quality reference values for rare earth elements in soils from one of the last agricultural
}

\section{frontiers in Brazil}

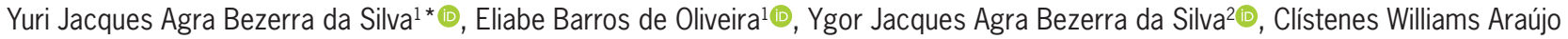

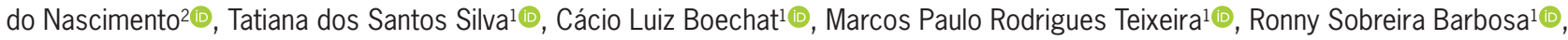 \\ Vijay P. Singh ${ }^{3}$, Antonny Francisco Sampaio de Sena1(i)
}

\begin{abstract}
${ }^{1}$ Universidade Federal de Piauí - Depto. de Agronomia, Campus Prof. Cinobelina Elvas, Rod. Bom Jesus-Viana, km 01 s/n - 64900-000 - Bom Jesus, PI - Brasil.

2Universidade Federal de Pernambuco - Depto. de Agronomia, R. Dom Manuel de Medeiros s/n - 52171-900 Recife, PE - Brasil.

${ }^{3}$ Texas A\&M University - Dept. of Biological and Agricultural Engineering - 77843-2117 - College Station, TX - USA.

*Corresponding author <yurijacques@ufpi.edu.br>
\end{abstract}

Edited by: Tiago Osório Ferreira

Received March 11, 2020

Accepted November 20, 2020
ABSTRACT: Environmental impacts caused by the addition of rare earth elements (REEs) to agricultural soils are a growing concern. The sedimentary basin of the Gurguéia River is located in one of the last agricultural frontiers in Brazil; nevertheless, data regarding quality reference values (QRVs) for REEs in soils are still scarce. The objective of this study was therefore to determine the natural concentration and establish the QRVs of REEs in soils of Gurguéia watershed, Brazil. Fifty-five composite soil samples were collected at sites under no or minimal anthropic interference. The average REE natural concentrations in soils from the Gurguéia watershed were lower than those found in other regions of Brazil and worldwide, following the order $\left(\mathrm{mg} \mathrm{kg}^{-1}\right)$ : $\mathrm{Ce}(14.01)>\mathrm{Nd}$ (6.19) > La (5.52) > $\operatorname{Pr}(2.51)>\mathrm{Sm}(1.45)>\mathrm{Gd}(0.93)>\mathrm{Dy}$ (0.63) $>\operatorname{Er}(0.42)>\mathrm{Yb}(0.39)>\mathrm{Tb}(0.28)>\mathrm{Eu}(0.26)>\mathrm{Lu}(0.20)$. The parent material was the main factor that controlled the distribution of REEs in soils. The QRVs in soils followed the order $\left(\mathrm{mg} \mathrm{kg}^{-1}\right)$ : $\mathrm{Ce}(18.8)>\mathrm{Nd}(7.92)>\mathrm{La}(6.32)>\operatorname{Pr}(3.3)>\mathrm{Sm}(1.97)>\mathrm{Gd}(1.35)>$ Dy (0.85) $>\operatorname{Er}(0.55)>\mathrm{Yb}(0.47)>\mathrm{Tb}(0.37)>\mathrm{Lu}(0.25)$. These values serve as a basis to assist the development of legislation, including REE thresholds for Brazilian soils.

Keywords: REE geochemistry, Gurguéia watershed, Oxisols, lanthanides

\section{Introduction}

Rare earth elements (REEs) are composed of 15 elements of the lanthanides $(\mathrm{Z}=57-71)$. These elements are usually separated into two groups known as light rare earth elements (LREEs; La-Eu) and heavy rare earth elements (HREEs; Gd-Lu) (Lara et al., 2018; Dinali et al., 2019; Silva et al., 2019). REEs are contained in more than 200 minerals, mainly in silicates, oxides, carbonates, phosphates and fluorides (Goodenough et al., 2016). The contents of REEs in soils are also influenced by the weathering processes and soil properties, such as $\mathrm{pH}$, organic matter, and clay mineral type (Mihajlovic et al., 2019; Santos et al., 2019).

REEs are essential for the industry, agriculture, and modern living. However, the increasing storage of REEs in soils has caused adverse impacts on the environment (Liu et al., 2019; Omodara et al., 2019) and human health (Bai et al., 2019; Pagano et al., 2019), especially in agricultural regions (Ramos et al., 2016; Silva et al., 2019; Jin et al., 2019). Knowledge on the background concentration and quality reference values (QRVs) is fundamental to manage soils properly, preventing risks to humans and environment (Nogueira et al., 2018).

Brazil is among the five largest countries in the world and has a great pedological variability. Therefore, establishing QRVs for REEs under different scales is critical for the proper management of the soils. In Brazil, despite recent efforts to determine the background concentrations of heavy metals in soils (Silva et al., 2016; Paye et al., 2016), the levels of QRVs for REEs in Brazilian soils are not established (Silva et al., 2018a), which can hinder the monitoring of REEs in the soils by environmental agencies.

The Gurgueita watershed represents one of the last agricultural frontiers in Brazil. The significant expansion of grain cultivation in this region stands out as one of the most important economic, agricultural, and industrial activities in northeastern Brazil. The accumulation of REEs in agricultural soils of this sedimentary basin has become a major environmental concern. Therefore, this study aimed to determine the natural concentration and establish the levels of QRVs of REEs in the soils of the Gurguéia watershed. Determining these values serves as a basis to assist the development of legislation, including thresholds for REEs in Brazilian soils.

\section{Materials and Methods}

\section{Study site}

The Gurguéia watershed covers $48,830 \mathrm{~km}^{2}$ of drainage area $\left(06^{\circ} 50^{\prime} 2.40^{\prime \prime}\right.$ and $10^{\circ} 55^{\prime} 44.40^{\prime \prime} \mathrm{S}$ and $43^{\circ} 23^{\prime} 27.60^{\prime \prime}$ and $44^{\circ} 55^{\prime} 55.20^{\prime \prime} \mathrm{W}$, altitude of $\left.621 \mathrm{~m}\right)$. The main watercourse stretches for $520 \mathrm{~km}$ and supplies water to 33 municipalities. Among the municipalities of the basin, Gilbués and Monte Alegre stand out as sites under desertification processes. In addition to the predominant influence of the Savana biome, considered one of the 35 hotspots of biodiversity in the world (Mittermeier et al., 2011), there is also a Savana-Caatinga transition area.

The average annual temperature is equal to $26^{\circ} \mathrm{C}$. The average annual rainfall ranges from 700 to $1300 \mathrm{~mm}$, characterized by high concentration from Dec to Mar. 
The soils are mainly derived from sedimentary rocks, except limestones. Soils originated from igneous and metamorphic rocks are also observed to a smaller extent.

The Gurguéia watershed consists of a wide erosive form derived mostly from river carving, equivalent to $14 \%$ of the intracratonic basin of Parnaíba (Pfaltzgraff et al., 2010). The Gurguéia watershed comprises, mainly, the supersequences Silurian, Denonian-Mississippian, and Pennsylvanian-Lower Triassic, which correspond to Serra Grande Group, Canindé Group, and Balsas Group, respectively (Oliveira and Moura, 2019). The Serra Grande Group is represented by conglomeratic sandstones at the bottom and fine sandstones at the top, interlayered by siltstones, shales and claystones (Pfaltzgraff et al., 2010). The Canidé Group (Pimenteiras, Cabeças, Longá and Poti Formations) is represented by fine-to-medium sandstones interlayered with bioturbated shales (Góes and Feijó, 1994; Oliveira and Moura, 2019).

The Balsas Group (Piauí Formation) corresponds to continental and coastal deposits, under arid conditions, represented by sandstones, shales and limestones (Góes and Feijó, 1994). A less representative part of the Gurguéia watershed is comprised of sandstones, siltstones, shale, and conglomerates of fluvial nature deposited in the units of the Areado Group of Cretaceous age (Fragoso et al., 2011; Oliveira et al., 2014), thick sequences of fluvial and aeolian sandstones, containing interleaving of siltstones and shale of the Urucuia Group, also deposited at Cretaceous (Pfaltzgraff et al., 2010; Oliveira et al., 2014), and colluvium-eluvial deposits of sand and alluvial deposits around the Gurguéia River (Pfaltzgraff et al., 2010). The metamorphic/igneous rocks found in the Gurguéia watershed are comprised of schist and phyllite of Proterozoic age (Rio Preto Group), as well as migmatite, orthogneisses, and paragneisses (metamafic and metaultramafic levels) of Archean age (Cristalândia do Piauí Complex) (Pfaltzgraff et al., 2010).

\section{Soil sampling}

Ten subsamples were collected at 0-20 $\mathrm{cm}$ depth (i.e. under the minimal anthropic influence) to form a composite sample soil at each of the 55 sampling sites to cover the diversity of parent materials and soils of the state (Figures $1 \mathrm{~A}$ and $1 \mathrm{~B}$ ).

\section{Soil preparation, physical and chemical analysis}

The soil sample was air-dried, sieved (2-mm nylon sieve), then grounded and passed through a stainless steel sieve (0.15-mm mesh). The soil $\mathrm{pH}$ was determined in water (soil:water ratio 1:2.5). The soil organic carbon (SOC) was analyzed by the Walkley-Black method (Yeomans and Bremmer, 1988). The soil sample was digested in Teflon vessel in a microwave oven (USEPA, 1998). The REEs were determined by inductively coupled plasma (ICP-OES). A cyclonic spray chamber was coupled to the ICP-OES to increase sensitivity to determine the REEs.

The standard operation and analytical data quality assurance procedures were followed, including the use of reference materials, such as San Joaquin Soil (2709a) and Montana Soil (2710a) (NIST, 2002). Recovery rates were satisfactory and ranged from $88 \%$ to $105 \%$; thus, this digestion method does not extract the contents strongly bounded to silicate minerals. Several authors have used this method to extract REEs from soils (BBodSchV, 1999;

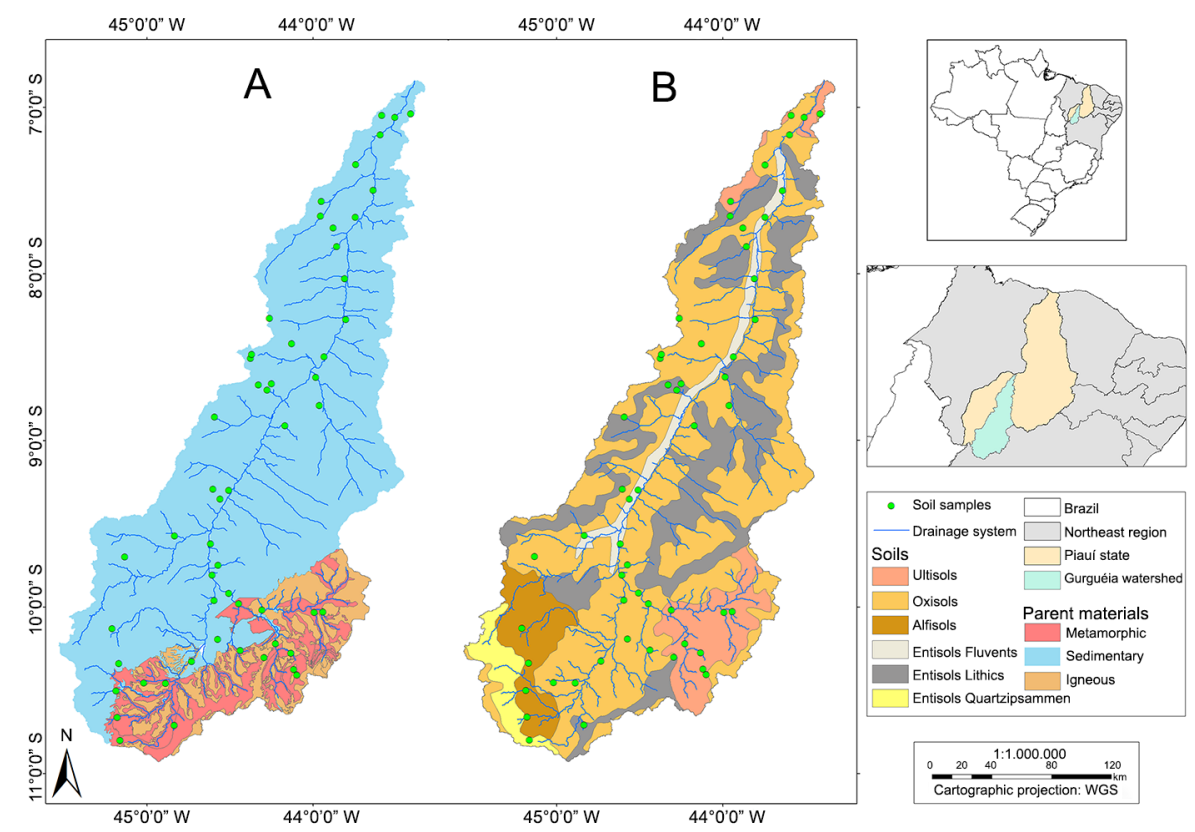

Figure 1 - Sampling sites according to the different parent materials (A) and soil classes (B) of the Gurguéia River sedimentary basin, southern Piauí, northeastern Brazil (CPRM, 2010). 
Rao et al., 2010; Loell et al., 2011; Mercurio et al., 2014; Mihajlovic et al., 2014; Censi et al., 2014; Alfaro et al., 2018; Silva et al., 2018a; Mihajlovic et al., 2019).

Major elements were measured by wavelength dispersive X-ray fluorescence (WDXRF, S8 TIGER ECOWDXRF). Samples were heated at $1000{ }^{\circ} \mathrm{C}$ for $1 \mathrm{~h}$ to obtain the loss on ignition. The results were used to calculate the chemical index of alteration (CIA) (Nesbitt and Young, 1982):

$$
C I A=\left[\mathrm{Al}_{2} \mathrm{O}_{3} /\left(\mathrm{Al}_{2} \mathrm{O}_{3}+\mathrm{Na}_{2} \mathrm{O}+\mathrm{CaO}+\mathrm{K}_{2} \mathrm{O}\right)\right] \times 100
$$

The ClA values increase with the depletion of cations $\left(\mathrm{Ca}^{2+}, \mathrm{K}^{+}\right.$, and $\left.\mathrm{Na}^{+}\right)$. Aluminum is relatively immobile; therefore, it is often used as an indicator to evaluate the intensity of chemical weathering of rocks and their respective soils (Alfaro et al., 2018; Silva et al., 2018b; Santos et al., 2019). Muscovite has CIA values around $75 \%$ and kaolinite has a value close to $100 \%$ (Nesbitt and Young, 1982).

\section{Normalization, fractionation and anomaly}

The contents of REEs of the upper continental crust (UCC; Taylor and McLennan, 1985) were used to normalize the concentration of REEs in soils of the Gurguéia watershed. The UCC has been commonly used to evaluate the enrichment and depletion patterns of REEs in soil samples (Cunha et al., 2018; Silva et al., 2018b; Mihajlovic et al., 2019). The $\mathrm{La}_{\mathrm{N}} / \mathrm{Yb}_{\mathrm{N}^{\prime}} \mathrm{Gd}_{\mathrm{N}} /$ $\mathrm{Yb}_{\mathrm{N}}$ and $\mathrm{La}_{\mathrm{N}} / \mathrm{Sm}_{\mathrm{N}}$ ratios were used to calculate the fractionation between LREEs/HREEs, HREEs and LREEs, respectively. The anomalies of $\mathrm{Ce}$ and $\mathrm{Eu}$ were calculated following Compton et al. (2003):

$$
\begin{aligned}
C e^{*} & =\frac{C e_{N}}{\left(L a_{N} * P r_{N}\right)^{0.5}} \\
E u^{*} & =\frac{E u_{N}}{\left(S m_{N} * G d_{N}\right)^{0.5}}
\end{aligned}
$$

where: $\mathrm{N}$ denotes the normalized values. The value below 1 indicates depletion (negative anomaly), while the value above 1 indicates enrichment in relation to the UCC (positive anomaly).

\section{Data analysis}

Results were analyzed using the descriptive statistics, multivariate techniques, and geostatistics. For the descriptive analyses, the maximum, minimum, median, mean, and standard deviation were calculated. The multivariate statistical analysis (factor analysis) was applied to verify the association between soil properties and the REEs. The varimax rotation was used to extract the most important variables (Kaiser, 1958). The variables were standardized and only eigenvalues $>1$ were selected. Soil QRVs were calculated based on $75^{\text {th }}$ percentile (CONAMA, 2009).
The geostatistical analyses were performed for the sums of LREE, HREE, REE and LREE/HREE to investigate the distribution of REEs according to soil classes and geological context. Adjustments were made via simple experimental semivariograms. Spherical, exponential, or Gaussian models were chosen based on the sum of squares of residuals (SSR), determination coefficient $\left(R^{2}\right)$, and the degree of spatial dependence (DSD). The DSD was calculated and interpreted following Cambardella et al. (1994).

\section{Results and Discussion}

\section{Natural content of REEs in soils}

The $\mathrm{pH}$ ranged from 3.6 to 6.3 (mean of $4.6 \pm 0.7$ ) with the predominance of the acidic condition. Data on particle size distribution shows that the soils are mostly sandy (mean of $77.7 \pm 9.4$ ). The clay and silt mean contents were $17 \%$ and 4.7 , respectively. The SOC contents were medium to low, varying from 0.01 to $1.8 \%$ (mean value of $0.9 \%$ ). The low cation exchange capacity is typical in the soils studied (Souza et al., 2019).

The average background concentrations of REEs in tropical soils of Gurguéia watershed followed the order $\left(\mathrm{mg} \mathrm{kg}^{-1}\right)$ : Ce (14.01) > Nd (6.19) > La (5.52) > $\operatorname{Pr}(2.51)>\operatorname{Sm}(1.45)>\operatorname{Gd}(0.93)>\operatorname{Dy}(0.63)>\mathrm{Er}$ $(0.42)>\mathrm{Yb}(0.39)>\mathrm{Tb}(0.28)>\mathrm{Eu}(0.26)>\mathrm{Lu}(0.20)$ (Table 1). These values were much lower than those found in soils from Brazil (Silva et al., 2016; Paye et al., 2016; Silva et al., 2018a), China (Wei et al., 1991), Japan (Yoshida et al., 1998), Cuba (Alfaro et al., 2018) and Europe (Sadeghi et al., 2013) (Table 1). The lowest concentrations of LREEs and HREEs in the soils from Gurguéia watershed are governed by parent material, with a predominance of soils originating from quartz sandstones. Silva et al. (2016) also showed that the parent material controlled the concentration of REEs in soils from the northeastern region of Brazil. They observed the lowest concentrations of REEs in soils derived from sedimentary rocks, demonstrating the importance of establishing QRVs considering a set of geomorphological, pedological, and geological compartments. The use of QRVs from other regions result in serious economic, social, and environmental losses.

The LREEs and HREEs represent $91 \%$ and $9 \%$ of the total rare earth elements, respectively. Among the LREEs, Ce was the most abundant, corresponding to $47 \%$ of the total concentration. The proportions observed for Ce and LREEs in this study were similar to those found by Wang and Liang (2016) in soils from China. In Brazil, several authors also showed Ce as the most abundant LREE, with proportions equivalent to $45 \%$ (Silva et al., 2016), $54 \%$ (Paye et al., 2016), and $47 \%$ (Silva et al., 2018a). The sum of REEs in the soils of Gurguéia watershed ranged from $4.23 \mathrm{mg} \mathrm{kg}^{-1}$ to $116 \mathrm{mg}$ $\mathrm{kg}^{-1}$, with an average concentration of about $32.94 \mathrm{mg}$ $\mathrm{kg}^{-1}$. These results are within the concentration range 
Table 1 - Average concentration of REEs in the soils of the sedimentary basin of the Gurguéia River watershed compared to the contents of REEs in Brazilian states, countries, Europe, and upper continental crust.

\begin{tabular}{|c|c|c|c|c|c|c|c|c|c|}
\hline REEs & Gurguéia & $P E^{1}$ & $\mathrm{RN}^{2}$ & Brazil $^{3}$ & China $^{4}$ & $\operatorname{Japan}^{5}$ & $\mathrm{Cuba}^{6}$ & Europe $^{7}$ & $\mathrm{UCC}^{8}$ \\
\hline & & & & 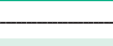 & $\mathrm{kg}^{-1}-$ & & & & - \\
\hline La & $5.52 \pm 3.5$ & 20.79 & 18.9 & 22.99 & 37.4 & 18.0 & 15.2 & 25.9 & 35 \\
\hline $\mathrm{Ce}$ & $14.01 \pm 9.1$ & 43.48 & 40.4 & 69.74 & 64.7 & 40.0 & 24.2 & 52.2 & 66 \\
\hline $\mathrm{Pr}$ & $2.51 \pm 1.8$ & 9.61 & 7.3 & 6.44 & 6.67 & 4.53 & 5.03 & 6.02 & 9.1 \\
\hline $\mathrm{Nd}$ & $6.19 \pm 4.1$ & 17.7 & 15.8 & 22.99 & 25.1 & 18.0 & 17.1 & 22.4 & 40 \\
\hline Sm & $1.45 \pm 1.0$ & 3.37 & 3 & 4.47 & 4.94 & 3.74 & 4.40 & 4.28 & 7 \\
\hline Eu & $0.26 \pm 0.1$ & 0.6 & 0.5 & 0.63 & 0.98 & 1.03 & 0.03 & 0.85 & 2.1 \\
\hline $\mathrm{Gd}$ & $0.93 \pm 0.7$ & 2.32 & 2.6 & 3.61 & 4.38 & 3.72 & 0.15 & 4.20 & 6.1 \\
\hline $\mathrm{Tb}$ & $0.28 \pm 0.2$ & 0.5 & 0.5 & 0.51 & 0.58 & 1.22 & 1.21 & 0.64 & 1.2 \\
\hline Dy & $0.63 \pm 0.5$ & 0.93 & 1 & 2.75 & 3.93 & 3.33 & 1.31 & 3.58 & 4.5 \\
\hline Ho & nd & 0.17 & 0.3 & 0.52 & 0.83 & 0.71 & 0.55 & 0.72 & 1.3 \\
\hline Er & $0.42 \pm 0.3$ & 0.59 & 0.7 & 1.51 & 2.42 & 2.02 & 2.36 & 2.10 & 3.5 \\
\hline Tm & nd & nd & nd & 0.22 & 0.24 & 0.29 & 0.02 & 0.33 & 0.33 \\
\hline $\mathrm{Yb}$ & $0.39 \pm 0.2$ & 0.67 & 0.6 & 1.49 & 2.32 & 2.01 & 1.86 & 3.10 & 3.1 \\
\hline Lu & $0.2 \pm 0.1$ & 0.05 & 0.2 & 0.22 & 0.35 & 0.34 & 0.77 & 0.80 & 0.8 \\
\hline$\sum$ LREE & $29.95 \pm 19.6$ & 95.55 & 85.9 & 127.26 & 140 & 85.2 & 65.9 & 159 & 159 \\
\hline$\sum$ HREE & $2.99 \pm 2.3$ & 5.23 & 5.9 & 10.83 & 14.8 & 13.2 & 8.21 & 51.5 & 20.8 \\
\hline$\sum$ REE & $32.94 \pm 21.8$ & 100.78 & 91.9 & 134.09 & 155 & 98.4 & 74.1 & 211 & 180 \\
\hline$\Sigma$ LREE/ $\Sigma$ HREE & $10.02 \pm 2.8$ & 18.27 & 14.56 & 11.75 & 9.43 & 6.45 & 8.03 & 7.76 & 7.64 \\
\hline
\end{tabular}

${ }^{1}$ Silva et al. (2016); ${ }^{2}$ Silva et al. (2018a); ${ }^{3 P}$ Paye et al. (2016); ${ }^{4}$ Wei et al. (1991); ${ }^{5}$ Yoshida et al. (1998); ${ }^{6}$ Alfaro et al. (2018); ${ }^{7}$ Sadeghi et al. (2013); ${ }^{8}$ UCC = upper continental crust; $n d=$ non detected. REEs = rare earth elements; $L R E E=$ light rare earth elements; and HREE = heavy rare earth elements.

of REEs found in soils (Tyler, 2004; Hu et al., 2006), but lower than the values often reported for Brazilian soils (Table 1).

The REE average concentration per soil type followed the order $\left(\mathrm{mg} \mathrm{kg}^{-1}\right)$ : Ultisols (72.56) > Alfisols (39.58) > Entisols Lithics (35.91) > Oxisols (25.13) $>$ Entisols Fluvents (15.32) (Figure 2A). The Ultisols showed the highest REE concentrations because they were mainly derived from igneous and metamorphic rocks (Figure 2B). The lowest levels were observed in Entisols Fluvents, which reflect their composition known to be enriched in quartz sediments. These results are in agreement with those shown by Silva et al. (2018a) and Alfaro et al. (2018), who observed that even under humid tropical patterns, the parent material played an important role in the geochemistry of the REEs. Soils derived from igneous rocks tend to have the highest concentrations of the REEs (Hu et al., 2006). Additionally, the influence of other soil formation factors and pedogenetic processes on the geochemistry of the REEs, as variations in the levels of REEs among the same soil class, might also occur.

\section{Quality reference values of REEs in soils}

Although REEs are considered emerging pollutants to the environment in Brazil, there are still no guidelines about the presence of these elements in the soil. Therefore, the ongoing expansion of the agricultural sector in Brazil, one of the world's largest food producers, and the lack of QRVs for REE in soils has been a growing concern. Thus, the of QRVs for REEs in soils of the sedimentary basin of the Gurguéia River were established following
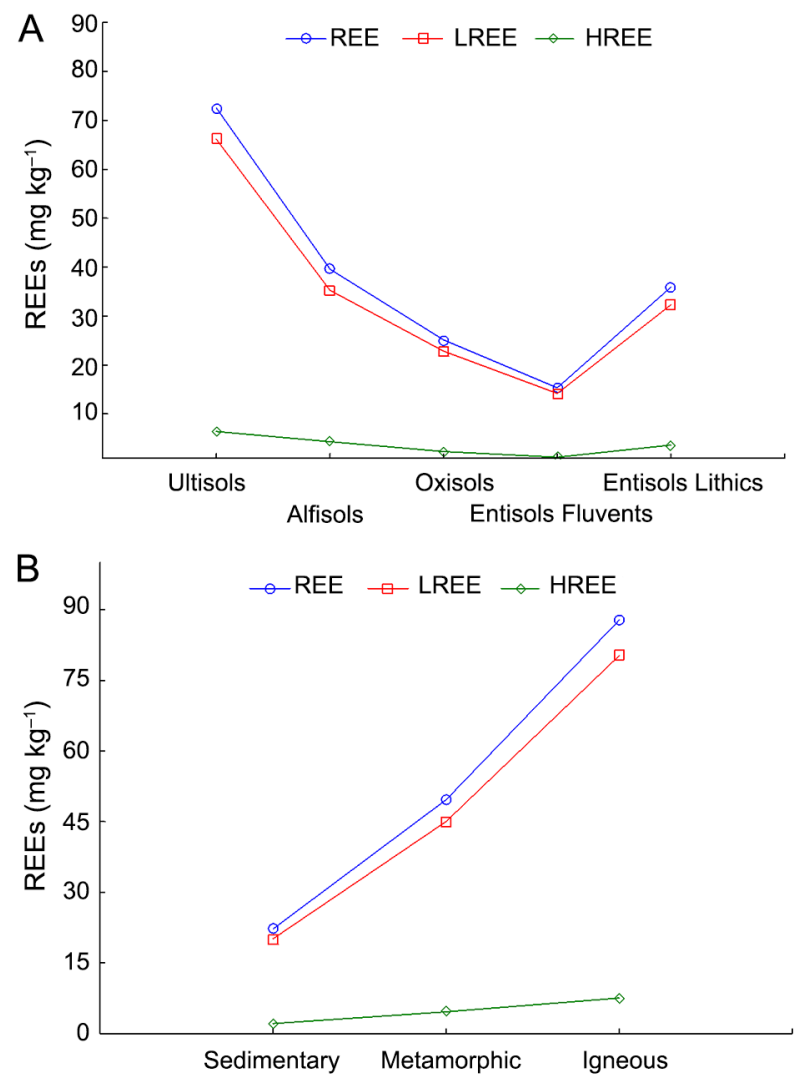

Figure 2 - Mean contents of REEs ( $\mathrm{mg} \mathrm{kg}^{-1}$ ) in the soils of the Gurguéia watershed (A) Average concentration of REEs per soil class and (B) Average concentration of REEs per parent material. REE refers to the sum of REEs. 
the guidelines proposed by the National Council of the Environment (CONAMA, 2009) for the monitoring of heavy metals in soils. The QRVs were calculated based on the $75^{\text {th }}$ percentile, as it is considered more conservative than the $90^{\text {th }}$ percentile, which excludes only $10 \%$ of the highest values, therefore, preferred by private agencies (Santos and Alleoni, 2013). The $75^{\text {th }}$ percentile has already been widely used to monitor heavy metals in several Brazilian states (Biondi et al., 2011; Santos et al., 2018; Preston et al., 2014; Almeida Júnior et al., 2016; Melo et al., 2017; Nogueira et al., 2018).

The QRVs for soils followed the order $\left(\mathrm{mg} \mathrm{kg}^{-1}\right)$ : Ce $(18.8)>\mathrm{Nd}(7.92)>\operatorname{La}(6.32)>\operatorname{Pr}(3.3)>\mathrm{Sm}(1.97)>$ $\operatorname{Gd}(1.35)>\mathrm{Dy}(0.85)>\operatorname{Er}(0.55)=\mathrm{Yb}(0.47)>\mathrm{Tb}(0.37)$ $>\mathrm{Lu}$ (0.25). In general, the QRVs for LREEs in the soils from Gurguéia watershed were lower than in soils from Rio Grande do Norte State (percentile $75^{\text {th }}, \mathrm{mg} \mathrm{kg}^{-1}$ ): Ce $(24.21)>\operatorname{La}(10.94)>\mathrm{Nd}(9.48)>\operatorname{Pr}(4.32)>\mathrm{Sm}(1.87)$ $>\operatorname{Gd}(1.52)>\operatorname{Dy}(0.69)>\operatorname{Er}(0.43)>\mathrm{Yb}(0.33)>\mathrm{Tb}$ $(0.32)>\operatorname{Ho}(0.21)>\operatorname{Lu}(0.10)>\mathrm{Tm}$ (0.09). Rio Grande do Norte is the only Brazilian state that has established QRVs for REEs in soils (Silva et al., 2018a); therefore, it is crucial to establish QRVs values, considering a set of geomorphological, pedological, and geological compartments. These values serve as a basis to create a legislation, including thresholds of REEs for Brazilian soils. However, the lack of QRVs for REEs in soils is not only a concern in Brazil, but also worldwide. Based on the great variability of Brazilian soils, future studies should seek to improve the resolution of the soil sampling in order to develop QRVs for local conditions, taking into account the specific geochemical characteristics.

\section{Influence of soil properties and major elements on the concentration of REEs in the soils across Gurguéia watershed}

The concentration of major elements $(\%)$ followed the order: $\mathrm{Si}>\mathrm{Al}>\mathrm{Fe}>\mathrm{K}>\mathrm{Mg}>\mathrm{Ti}>\mathrm{Na}>\mathrm{Ca}>$ $\mathrm{Mn}$ (Table 2). Soils with the highest proportion of silica (Entisols Fluvents) presented the lowest concentrations of REEs (data not shown). In contrast, clayey soils with lower proportions of $\mathrm{SiO}_{2}$, such as Ultisols derived from igneous rocks, exhibited the highest concentrations of REEs (Figures 2A and 2B). Alfaro et al. (2018) studied the geochemistry of the REEs in soils developed under different geological settings and reported similar results. For instance, the lowest $\Sigma$ REE mean content $(12.0 \mathrm{mg}$ $\mathrm{kg}^{-1}$ ) was detected in Typic Kandiustalf soil, with the highest values of $\mathrm{SiO}_{2}(73 \%)$. On the other hand, Typic Rhodudalf and Rhodic Eutrodox soils showed the lowest concentration of $\mathrm{SiO}_{2}(22-25 \%)$, with the contents of ¿REE roughly four-fold higher than those of soils from other parent materials.

Soils of the sedimentary basin of Gurguéia River exhibited weathering rates ranging from intermediate to advanced, with the CIA ranging from $69.9 \%$ to $99.7 \%$, with an average of $93.6 \%$ (Table 2). Ultisols and
Table 2 - Proportions of major elements, CIA, clay and sand in tropical soils of a sedimentary basin in northeast Brazil.

\begin{tabular}{lrrrrr}
\hline Oxides & Maximum & Minimum & Median & Mean & \multicolumn{1}{c}{$\mathrm{SD}$} \\
\hline $\mathrm{Na}_{2} \mathrm{O}$ & 1.62 & 0.01 & 0.06 & 0.13 & 0.26 \\
$\mathrm{MgO}$ & 2.35 & 0.01 & 0.10 & 0.22 & 0.39 \\
$\mathrm{Al}_{2} \mathrm{O}_{3}$ & 28.64 & 6.55 & 16.60 & 16.79 & 5.60 \\
$\mathrm{SiO}_{2}$ & 88.94 & 50.36 & 72.75 & 72.48 & 9.63 \\
$\mathrm{~K}_{2} \mathrm{O}$ & 6.48 & 0.03 & 0.42 & 0.89 & 1.24 \\
$\mathrm{CaO}$ & 0.93 & 0.02 & 0.04 & 0.11 & 0.18 \\
$\mathrm{TiO}_{2}$ & 1.94 & 0.31 & 0.86 & 0.94 & 0.37 \\
$\mathrm{MnO}_{\mathrm{Fe}} \mathrm{O}_{3}$ & 0.11 & 0.01 & 0.01 & 0.02 & 0.03 \\
$\mathrm{ClA}_{\mathrm{Clay}}$ & 8.06 & 0.40 & 2.10 & 2.68 & 1.84 \\
Sandy & 99.69 & 69.87 & 92.94 & 93.58 & 5.88 \\
\hline $\mathrm{CIA}=\mathrm{Ch}$ & 38.40 & 2.4 & 14.12 & 17.56 & 5.08 \\
\hline
\end{tabular}

$\overline{\mathrm{CIA}}=$ Chemical Index of Alteration; SD = Standard Deviation.

Alfisols derived from igneous and metamorphic rocks presented the lowest CIA values and, consequently, the highest concentrations of REEs (Figure 2A). These results indicate that the soil class and geological context of the region control geochemistry of REEs in soils. We applied the factor analysis to provide more details on the association among major elements, soil properties and REEs in the soils (Table 3). The $\mathrm{P}_{2} \mathrm{O}_{5^{\prime}}, \mathrm{TiO}_{2}, \mathrm{ZrO}_{2}$, $\mathrm{Cr}_{2} \mathrm{O}_{3}, \mathrm{SrO}_{2} \mathrm{SO}_{3}, \mathrm{BaO}, \mathrm{Na}_{2} \mathrm{O}, \mathrm{SOC}$, and $\mathrm{pH}$ were ruled out due to their little contribution. The three factors presented eigenvalues higher than one $(\mathrm{F} 1=17, \mathrm{~F} 2=$ 4.1 and F3 = 2.1) and explained approximately $87 \%$ of the variation of REEs in the soils (Table 3).

Factor 1 showed a positive correlation with $\Sigma$ REEs (0.91), ELREEs (0.95) and EHREEs (0.93) and negatively correlated with sand $(-0.65)$, which can be explained by the dilution effect of quartz on the concentration of REEs. Factor 2 showed positive correlation with $\mathrm{Lu}$ (0.77), $\mathrm{Al}_{2} \mathrm{O}_{3}$ (0.88), $\mathrm{Fe}_{2} \mathrm{O}_{3}$ (0.91), and clay (0.71), indicating a better correlation of $\mathrm{Lu}$ with $\mathrm{Al}_{2} \mathrm{O}_{3}$ and $\mathrm{Fe}_{2} \mathrm{O}_{3}$. This factor was negatively correlated with $\mathrm{SiO}_{2}(-0.91)$. F3 showed a positive and highly significant correlation with $\mathrm{MgO}(0.87), \mathrm{K}_{2} \mathrm{O}(0.84)$, and $\mathrm{CaO}$ (0.85) and a negative correlation with CIA $(-0.80)$ due to the leaching of these bases with the increased intensity of weathering. Both $\mathrm{pH}$ and SOC did not affect the distribution of REEs. However, Silva et al. (2016) and Vermeire et al. (2016) demonstrated the influence of SOC and $\mathrm{pH}$ on the concentration of REEs, suggesting that the composition and interaction of chemical compartments of OM with REEs might affect their geochemistry.

\section{Fractionation and anomalies of REEs in soils}

The concentrations of REEs were normalized using the UCC (Taylor and McLennan, 1985). The normalized concentrations, according to the soil class (Figure 3A) and parent material (Figure 3B), demonstrated depletion in relation to the continental earth's crust /values are 
Table 3 - Influence of major elements and soil properties on the distribution of REEs in tropical soils of a sedimentary basin in northeast Brazil.

\begin{tabular}{|c|c|c|c|}
\hline Variables & F1 & F2 & F3 \\
\hline $\mathrm{La}$ & 0.89 & 0.10 & 0.24 \\
\hline $\mathrm{Ce}$ & 0.88 & 0.19 & 0.31 \\
\hline $\mathrm{Pr}$ & 0.92 & 0.17 & 0.22 \\
\hline $\mathrm{Nd}$ & 0.94 & 0.19 & 0.21 \\
\hline $\mathrm{Sm}$ & 0.94 & 0.23 & 0.20 \\
\hline Eu & 0.85 & 0.31 & 0.19 \\
\hline $\mathrm{Gd}$ & 0.91 & 0.08 & 0.34 \\
\hline$Y b$ & 0.90 & 0.34 & 0.06 \\
\hline Lu & 0.46 & 0.77 & -0.04 \\
\hline Dy & 0.98 & 0.06 & 0.07 \\
\hline $\mathrm{Er}$ & 0.94 & 0.21 & 0.11 \\
\hline $\mathrm{Tb}$ & 0.83 & 0.49 & 0.09 \\
\hline LREES & 0.91 & 0.18 & 0.27 \\
\hline HREES & 0.95 & 0.21 & 0.19 \\
\hline REEs & 0.93 & 0.18 & 0.26 \\
\hline $\mathrm{MgO}$ & 0.18 & 0.08 & 0.87 \\
\hline $\mathrm{Al}_{2} \mathrm{O}_{3}$ & 0.10 & 0.88 & -0.07 \\
\hline $\mathrm{SiO}_{2}$ & -0.17 & -0.91 & -0.08 \\
\hline $\mathrm{K}_{2} \mathrm{O}$ & 0.35 & -0.04 & 0.84 \\
\hline $\mathrm{CaO}$ & 0.26 & 0.04 & 0.85 \\
\hline $\mathrm{Fe}_{2} \mathrm{O}_{3}$ & 0.18 & 0.91 & 0.01 \\
\hline CIA & -0.29 & 0.25 & -0.80 \\
\hline$\%$ Sand & -0.65 & -0.62 & -0.35 \\
\hline$\%$ Clay & 0.30 & 0.76 & -0.22 \\
\hline Explained variance (\%) & 64 & 15 & 7.9 \\
\hline Eigenvalues & 17 & 4.1 & 2.1 \\
\hline
\end{tabular}

Significant loads are in bold.

lower than a unity). These results could be explained by the geological context of the sedimentary basin of the Gurguéia River, with a predominance of soils originating from sandstones, which exhibit low concentrations of REEs in comparison to UCC.

The soil classes presented positive $\mathrm{Ce}$ and negative $\mathrm{Eu}$ anomalies, decreasing in the following order: Ultisols $(37.68 ; 0.51)>$ Alfisols $(18.24 ; 0.35)>$ Entisols Lithics $(17.65 ; 0.28)>$ Oxisols $(12.16 ; 0.19)$ and Entisols Fluvents $(7.74 ; 0.10)$, respectively (Table 4). Variation in the positive anomalies for $\mathrm{Ce}$ and negative for $\mathrm{Eu}$ are mainly influenced by mineralogical composition of the parent material. The Ultisols and Alfisols derived from igneous rocks, more clayey and with lower $\mathrm{SiO}_{2}$ content, exhibited the higher positive $\mathrm{Ce}$ anomalies and lower negative anomalies for $\mathrm{Eu}$, while the Entisols Fluvents, highly influenced by sediments, sandier, and with higher $\mathrm{SiO}_{2}$ content, presented the lower positive Ce anomalies, followed by higher negative anomalies of Eu.

The mean fractionation values between the ratios of LREEs, HREEs, and LREEs/HREEs, based on the ratios of $\mathrm{La}_{\mathrm{N}} / \mathrm{Sm}_{\mathrm{N}}, \mathrm{Gd}_{\mathrm{N}} / \mathrm{Yb}_{\mathrm{N}}$ and $\mathrm{La}_{\mathrm{N}} / \mathrm{Yb}_{\mathrm{N}}$, were $0.62,1.43$ and 1.18 , respectively. These data indicated that a depletion inside the LREE group with practically no fractionation
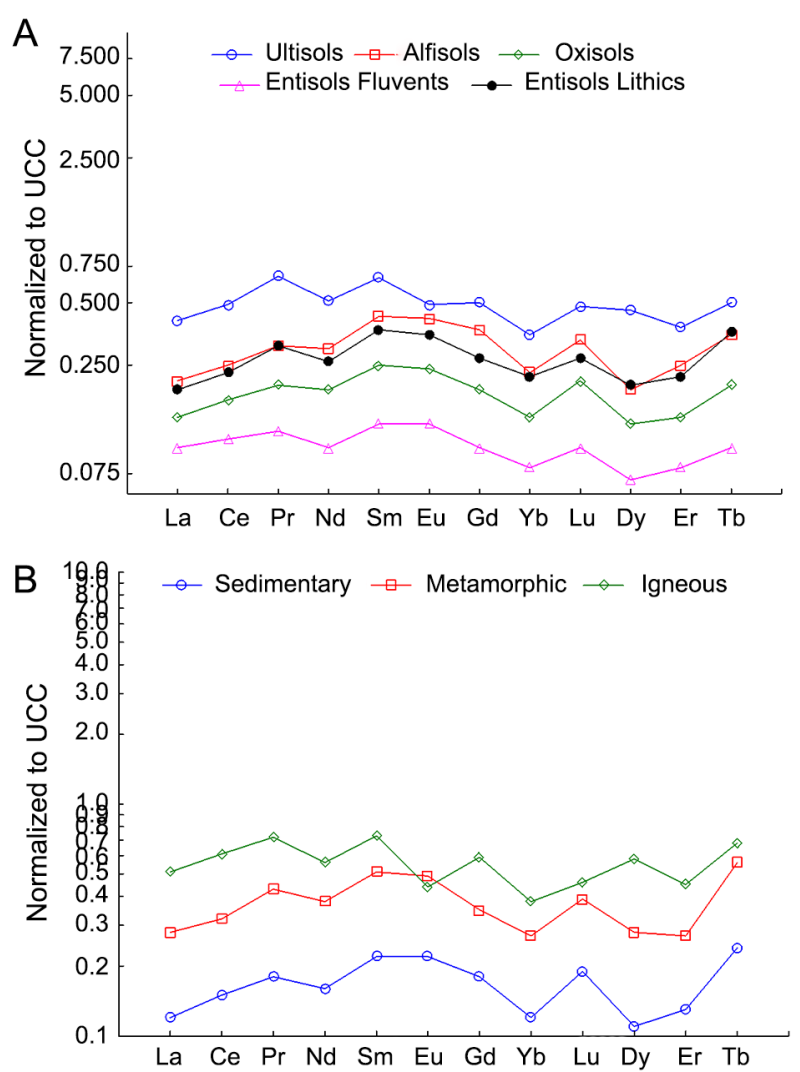

Figure 3-Behavior of REEs in the soils (A) and according to the parent material (B) across the Gurguéia watershed. Values are normalized to upper continental crust = UCC (Taylor and McLennan, 1985). Red line - values lower than " 1 " implies depletion and higher than "1", enrichment compared to the parent material.

between LREEs/HREEs in the soils of the sedimentary basin of Gurguéia River (Table 4, and Figures 3A and 3B). This might be explained by the naturally very low levels of REEs in the soils of the watershed, mainly originating from quartz sandstones, which showed lower concentrations of REEs in comparison to UCC (Taylor and McLennan, 1985).

\section{Geostatistical analysis}

The parameters of experimental semivariograms demonstrate that $\sum$ LREEs, HREEs, $\sum$ REEs, and ¿LREEs/HREEs had spatial dependence (Table 5). For all attributes, this spatial dependence was considered strong, according to the classification of Cambardella et al. (1994). Thus, dependence can be observed between values related to neighboring sites, evidencing homogeneity in the concentrations of REEs. Huang et al. (2019) identified a spatially homogeneous pattern in the distribution of REEs in soils and reported the same conditions. This relationship between neighboring locations occurred up to a certain distance indicated by range. 
Table 4 - Mean $\mathrm{Ce}$ and Eu anomalies and fractionation of REEs in tropical soils of a sedimentary basin in northeast Brazil.

\begin{tabular}{|c|c|c|c|c|c|c|}
\hline & & Ultisols & Alfisols & Oxisols & Entisols Fluvents & Entisols Lithics \\
\hline \multirow{4}{*}{$\mathrm{Ce} / \mathrm{Ce}^{*}$} & Mean & 37.68 & 18.24 & 12.16 & 7.74 & 17.65 \\
\hline & Min. & 4.19 & 5.39 & 3.12 & 2.19 & 5.03 \\
\hline & Max. & 58.39 & 34.05 & 33.34 & 13.98 & 39.31 \\
\hline & SD & 19.35 & 9.95 & 8.76 & 3.90 & 13.80 \\
\hline \multirow{4}{*}{$\mathrm{Eu} / \mathrm{Eu}^{*}$} & Mean & 0.51 & 0.35 & 0.19 & 0.10 & 0.28 \\
\hline & Min. & 0.09 & 0.14 & 0.04 & 0.04 & 0.05 \\
\hline & Max. & 1.05 & 0.55 & 0.85 & 0.23 & 0.66 \\
\hline & SD & 0.29 & 0.14 & 0.17 & 0.06 & 0.24 \\
\hline \multirow{4}{*}{$\mathrm{La}_{\mathrm{N}} N \mathrm{Yb}_{\mathrm{N}}$} & Mean & 1.18 & 0.91 & 1.02 & 1.23 & 0.88 \\
\hline & Min. & 0.66 & 0.80 & 1.14 & 1.21 & 1.10 \\
\hline & Max. & 1.29 & 0.84 & 0.54 & 0.74 & 0.68 \\
\hline & SD & 1.31 & 1.03 & 0.69 & 0.86 & 0.68 \\
\hline \multirow{4}{*}{$\mathrm{La}_{N} / \mathrm{Sm}_{\mathrm{N}}$} & Mean & 0.62 & 0.48 & 0.55 & 0.73 & 0.52 \\
\hline & Min. & 0.62 & 0.45 & 0.58 & 0.83 & 0.65 \\
\hline & Max. & 0.65 & 0.43 & 0.36 & 0.74 & 0.46 \\
\hline & SD & 0.70 & 0.51 & 0.42 & 0.83 & 0.44 \\
\hline \multirow{4}{*}{$\mathrm{Gd}_{N} N \mathrm{~b}_{N}$} & Mean & 1.43 & 1.61 & 1.39 & 1.23 & 1.22 \\
\hline & Min. & 0.19 & 1.23 & 0.58 & 0.58 & 1.01 \\
\hline & Max. & 1.49 & 2.16 & 1.60 & 0.87 & 0.98 \\
\hline & SD & 1.48 & 2.70 & 1.66 & 0.89 & 1.12 \\
\hline
\end{tabular}

$\mathrm{Ce} / \mathrm{Ce}^{*}=\mathrm{Ce}$ anomaly; $\mathrm{Eu} / \mathrm{Eu}^{*}=\mathrm{Eu}$ anomaly; $\mathrm{LaN} / \mathrm{YbN}=$ fractionation between LREEs and HREEs; LaN/SmN = fractionation between LREEs; GdN/ $\mathrm{YbN}=$ fractionation between HREEs; SD = Standard Deviation.

Table 5 - Model parameters fitted to the experimental semivariograms of REEs in tropical soils of a sedimentary basin in northeast Brazil.

\begin{tabular}{|c|c|c|c|c|c|c|c|}
\hline Variables & Model & $\mathrm{C}_{0}$ & $\mathrm{C}_{0}+\mathrm{C}_{1}$ & DSD & ESD & Range & $\mathrm{R}^{2}$ \\
\hline & & & & $\%$ & & $\mathrm{~m}$ & \\
\hline$\sum$ LREE & Exponential & 90.0 & 797.5 & 10 & $S$ & 64600 & 0.98 \\
\hline$\sum$ HREE & Exponential & 0.01 & 9.62 & 0.1 & $S$ & 33700 & 0.77 \\
\hline$\sum$ REE & Exponential & 107.0 & 966.8 & 10 & S & 62000 & 0.97 \\
\hline$\sum$ LREE/HREE & Exponential & 0.03 & 0.09 & 25 & $S$ & 17200 & 0.50 \\
\hline
\end{tabular}

The range for the sum of LREEs was close to that observed for the sum of REEs. On the other hand, the sum of HREEs presented a range lower than the previous two; however, higher than that presented by the sum of LREEs/HREEs (Table 1). This highlighted the importance of LREEs in the natural levels of REEs. Silva et al. (2018a) observed the same behavior in the spatial variability of REE in soils under different pedological and geological patterns.

The exponential model was the best to estimate the REE values in unsampled locations, showing $R^{2}$ values higher than 0.7. Silva et al. (2018a) also reported that the exponential model showed the best performance to the spatial distribution of most REEs. In addition, this behavior could also be related to the fact that these attributes are integrating the same factorial group (Table

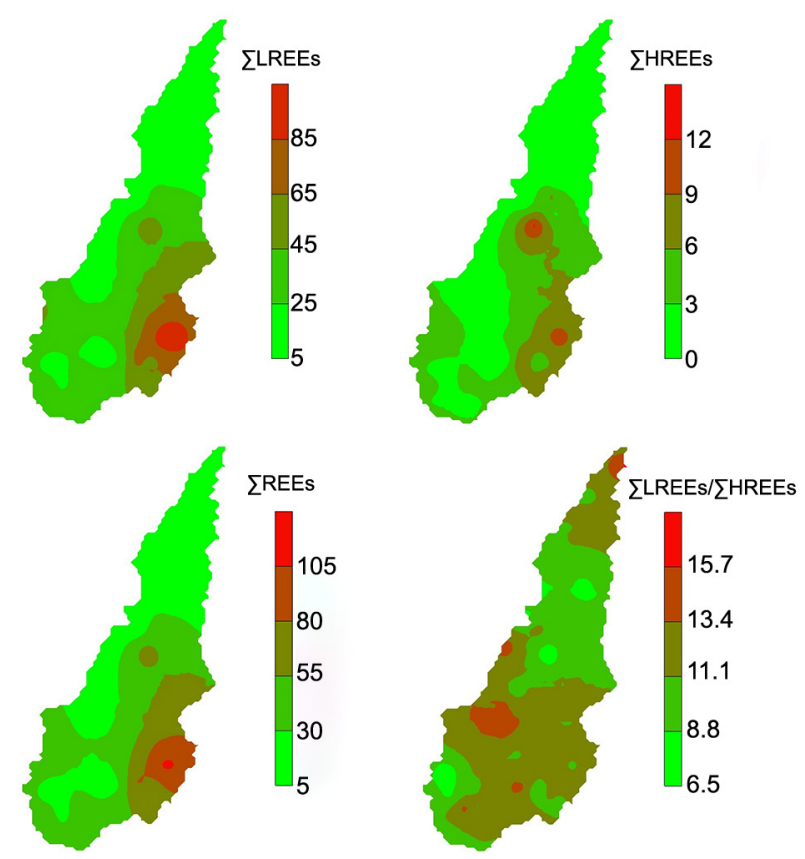

Figure 4 - Spatial distribution maps of $\Sigma$ LREEs, $\Sigma$ HREEs, $\Sigma$ REEs, and $\Sigma$ LREES/HREEs in tropical soils of a sedimentary basin in northeast Brazil.

3). Therefore, the highest concentrations of all sums were located in the central region of the basin and were spread throughout the southeastern region.

The highest concentrations of REEs (Figure 4) were located at the points of occurrence of igneous phanerozoic rocks, responsible for forming the "Ultisols". The soils derived from sedimentary rocks, located in the northwestern and northeastern regions of the Gurguéia watershed, presented the lowest levels of REEs (Figure 4).

\section{Conclusion}

The contents of REEs in tropical soils of the sedimentary basin of the Gurgueia River were low, controlled mainly by the parent material, with a predominance of soils derived from quartz sandstone. The highest concentrations were observed in Ultisols and Alfisols originating from igneous rocks. The average natural concentrations of REEs in the soils from the Gurgueia watershed were $\left(\mathrm{mg} \mathrm{kg}^{-1}\right)$ : Ce (14.01) > Nd (6.19) > La $(5.52)>\operatorname{Pr}(2.51)>\operatorname{Sm}(1.45)>\operatorname{Gd}(0.93)>\mathrm{Dy}(0.63)$ $>\operatorname{Er}(0.42)>\mathrm{Yb}(0.39)>\mathrm{Tb}(0.28)>\operatorname{Eu}(0.26)>\mathrm{Lu}$ (0.20). The average natural concentrations of REEs in soils from the Gurguéia watershed were lower than in other regions of Brazil and worldwide. There was a low geochemical association between REEs and major elements in soils of the Gurguéia watershed, except for the strong influence of $\mathrm{Fe}_{2} \mathrm{O}_{3}$ on $\mathrm{Lu}$ accumulation. This demonstrates the importance of establishing QRVs considering a set of geomorphological, pedological, and geological compartments. The spatial variability of REEs 
is mainly related to the parent material. These results serve as a reference for monitoring the quality of soils in this region, mainly due to the accelerated expansion of grain production. The establishment of QRVs for REEs in tropical soils of the Gurguéia watershed serves as a basis for the creation of legislation, including thresholds for REEs for Brazilian soils.

\section{Acknowledgments}

This work was supported by the National Council for Scientific and Technological Development CNPq (Process Number: 404394/2016-7) and by the Coordination for the Improvement of Higher Level Personnel (CAPES) that provided a scholarship to the second author. Clístenes Williams Araújo do Nascimento and Yuri Jacques Agra Bezerra da Silva are grateful to the National Council for Scientific and Technological Development (CNPq) for granting the research productivity scholarships (Process Numbers: 305782/2018-5, and 303221/2019-4).

\section{Authors' Contributions}

Conceptualization: Silva, Y.J.A.B.; Oliveira, E.B.; Silva, Y.J.A.B. Data acquisition: Silva, Y.J.A.B.; Oliveira, E.B.; Silva, Y.J.A.B.; Boechat, C.L.; Barbosa, R.S.; Teixeira, M.P.R. Design of methodology: Silva, Y.J.A.B.; Oliveira, E.B.; Silva, Y.J.A.B.; Boechat, C.L.; Silva, T.S.S.; Sena, A.F.S. Data analysis: Silva, Y.J.A.B.; Oliveira, E.B.; Silva, Y.J.A.B.; Nascimento, C.W.A.; Barbosa, R.S. Writing and editing: Silva, Y.J.A.B.; Oliveira, E.B.; Silva, Y.J.A.B.; Nascimento, C.W.A.; Singh, V.P.

\section{References}

Alfaro, M.R.; Nascimento, C.W.A.; Biondi, C.M.; Silva, Y.J.A.B.; Accioly, A.M.; Montero, A.; Ugarte, O.M.; Estevez, J. 2018. Rare-earth-element geochemistry in soils developed in different geological settings of Cuba. Catena 162: 317-324. https://doi. org/10.1016/j.catena.2017.10.031

Almeida Júnior, A.B.; Nascimento, C.W.A.; Biondi, C.M.; Souza, A.P.; Barros, F.M.R. 2016. Background and reference values of metals in soils from Paraíba state, Brazil. Revista Brasileira de Ciência do Solo 40: e0150122. https://doi.org/10.1590/1806965 7rbcs20150122

Bai, Y.; Long, C.; Hu, G.; Di Zhou, D.; Xiaoying Gao, X.; Chen, Z.; Wang, T.; Yu, S.; Han, Y.; Yan, L. 2019. Association of blood chromium and rare earth elements with the risk of DNA damage in chromate exposed population. Environmental Toxicology and Pharmacology 72: 103237. https://doi. org/10.1016/j.etap.2019.103237

Biondi, C.M.; Nascimento, C.W.A.; Fabricio Neto, A.B.; Ribeiro, M.R. 2011. Concentrations of $\mathrm{Fe}, \mathrm{Mn}, \mathrm{Zn}, \mathrm{Cu}, \mathrm{Ni}$ and Co in benchmark soils of Pernambuco, Brazil. Revista Brasileira de Ciência do Solo 35: 1057-1066 (in Portuguese, with abstract in English). https://doi.org/10.1590/S010006832011000300039
Cambardella, C.A.; Moorman, T.B.; Parkin, T.B.; Karlen, D.L.; Novak, J.M.; Turco, R.F.; Konopka, A.E. 1994. Field-scale variability of soil properties in central Iowa soil. Soil Science Society of America Journal 58: 1501-11. https://doi.org/10.2136/ sssaj1994.03615995005800050033x

Censi, P.; Saiano, F.; Pisciotta, A.; Tuzzolino, N. 2014. Geochemical behaviour of rare earths in Vitis vinifera grafted onto different rootstocks and growing on several soils. Science of the Total Environment 473-474: 597-608. https://doi.org/10.1016/j. scitotenv.2013.12.073

Companhia de Pesquisa de Recursos Minerais [CPRM]. 2010. Geodiversity of the state of Piaui $=$ Geodiversidade do estado do Piauí. CPRM/SGB, Brasília, DF, Brazil. Available at: http://rigeo. cprm.gov.br/jspui/bitstream/doc/14708/4/gdpi_lito.zip [Accessed Mar 18, 2019] (in Portuguese).

Compton, J.S.; White, R.A.; Smith, S. 2003. Rare earth element behavior in soli sans salt pan sediments of a semiarid granitic terrain in the Western Cape, South Africa. Chemical Geology 201: 239-255. https://doi.org/10.1016/S0009-2541(03)00239-0

Conselho Nacional do Meio Ambiente [CONAMA]. 2009. Resolution $\mathrm{N}^{\circ} 420$ of Dec 28, 2009. Provides guiding values and criteria of soil quality for the presence of chemicals and establishes guidelines for environmental management of areas contaminated by these substances as a result of anthropogenic activities = Dispõe sobre critérios e valores orientadores de qualidade do solo quanto à presença de substâncias químicas e estabelece diretrizes para o gerenciamento ambiental de áreas contaminadas por essas substâncias em decorrência de atividades antrópicas. Available at: http://www.mma.gov.br/port/conama/legiabre.cfm?codlegi0620 [Accessed Jan 20, 2020] (in Portuguese).

Cunha, C.S.M.; Silva, Y.J.A.B.; Escobar, M.E.O.; Nascimento, C.W.A. 2018. Spatial variability and geochemistry of rare earth elements in soils from the largest uranium-phosphate deposit of Brazil. Environmental Geochemistry and Health 40: 1629-1643. https://doi.org/10.1007/s10653-018-0077-0

Dinali, G.S.; Root, R.A.; Amistadi, M.K.; Chorover, J.; Lopes, G.; Guilherme, L.R.G. 2019. Rare earth elements (REY) sorption on soils of contrasting mineralogy and texture. Environment International 128: 279-291. https://doi.org/10.1016/j. envint.2019.04.022

Federal Soil Protection and Contaminated Sites Ordinance [BBodSchV]. 1999. Federal Soil Protection and Contaminated Sites Ordinance. Available in: https://www.elaw.org/content/ germany-federal-soil-protection-and-contaminated-sitesordinance-bbodschv-12-july-1999 [Accessed Jan 18, 2017]

Goodenough, K.M.; Schilling, J.; Jonsson, E.; Kalvig, P.; Charles, N.; Tuduri, J.; Deady, E.A.; Sadeghi, M.; Schiellerup, H.; Muller, A.; Bertrand, G.; Arvanitidis, N.; Eliopoulos, D.G.; Shaw, R.A.; Thrane, K.; Keulen, N. 2016. Europe's rare earth element resource potential: an overview of REE metallogenetic provinces and their geodynamic setting. Ore Geology Reviews 72: 838-856. https://doi.org/10.1016/j.oregeorev.2015.09.019

Fragoso, D.G.C.; Uhlein, A.; Sanglard, J.C.D.; Suckau, G.L.; Guerzoni, H.T.G.; Faria, P.H. 2011. Geology of bambui, areado and mata da corda groups in the Presidente Olegário sheet (1:100.000), MG: neoproterozoic to late cretaceous depositional record of the São Francisco basin. Genomos 19: 28-38 (in Portuguese, with abstract in English). https://doi.org/10.18285/geonomos.v19i1.60 
Góes, A.M.O.; Feijó, F.J. 1994. Parnaíba Basin = Bacia do Parnaíba. Boletim Geociências 8: 57-67 (in Portuguese).

Huang, H.; Lin, C.; Yu, R.; Yan, Y.; Hu, G.; Wang, Q. 2019. Spatial distribution and source appointment of rare earth elements in paddy soils of Jiulong River Basin, southeast. China. Journal of Geochemical Exploration 200: 213-220. https://doi.org/10.1016/j.gexplo.2018.09.008

Hu, Z.; Haneklaus, S.; Sparovek, G.; Schnug, E. 2006. Rare earth elements in soils. Communications in Soil Science and Plant Analysis 37: 1381-1420. https://doi. org/10.1080/00103620600628680

Jin. S.; Hu. Z.J.; Man. B.; Pan, H. 2019. Application of phosphate-containing materials affects bioavailability of rare earth elements and bacterial community in soils. Science China Technological Sciences 62: 1616-1627. https://doi. org/10.1007/s11431-018-9426-3

Kaiser, H.F. 1958. The Varimax criterion for analytic rotation in factor analysis. Psychometrika 23: 187-200.

Lara, M.C.; Buss, H.L.; Pett-Ridge, J.C. 2018. The effects of lithology on trace element and REE behavior during tropical weathering. Chemical Geology 500: 88-102. https://doi. org/10.1016/j.chemgeo.2018.09.024

Liu, W.S.; Guo, M.N.; Liu, C.; Yuan, M.; Chen, X.T.; Huot, H.; Zhao, C.M.; Tang, Y.T.; Morel, J.L.; Qiu, R.L. 2019. Water, sediment and agricultural soil contamination from an ionadsorption rare earth mining area. Chemosphere 216: 75-83. https://doi.org/10.1016/j.chemosphere.2018.10.109

Loell, M.; Albrecht, C.; Henningsen, P.F. 2011. Rare earth elements and relation between their potential bioavailability and soil properties. Plant and Soil 349: 303-317. https://doi. org/10.1007/s11104-011-0875-y

Melo, V.F.; Buschle, B.; Souza, L.C.P.; Bonfleur, E.J. 2017. Reference values for potentially harmful elements in soils from Atlantic Rainforest, Brazil. Journal of Geochemical Exploration 181: 138-147. https://doi.org/10.1016/j. gexplo.2017.07.009

Mercurio, M.; Grilli, E.; Odierna, P.; Morra, V.; Prohaska, T.; Coppola, E.; Grifa, C.; Buondonno, A.; Langella, A. 2014. A 'Geo-Pedo-Fingerprint' (GPF) as a tracer to detect univocal parent material-to-wine production chain in high quality vineyard districts, Campi Flegrei (southern Italy). Geoderma 230-231: 64-78. https://doi.org/10.1016/j. geoderma.2014.04.006

Mihajlovic, J.; Stark, H.J.; Rinklebe, J. 2014. Geochemical fractions of rare earth elements in two floodplain soil profiles at the Wupper River, Germany. Geoderma 228-229: 160-172. https://doi.org/10.1016/j.geoderma.2013.12.009

Mihajlovic, J.; Bauriegel, A.; Stärk, H.J.; Roßkopf, N.; Zeitz, J.; Milbert, G.; Rinklebe, J. 2019. Rare earth elements in soil profiles of various ecosystems across Germany. Applied Geochemistry 102: 197-217. https://doi.org/10.1016/j. apgeochem.2019.02.002

Mittermeier, R.A.; Turner, W.R.; Larsen, F.W.; Brooks, T.M.; Gascon, C. 2011. Global biodiversity conservation: the critical role of hotspots. p. 3-22. In: Zachos, F.E.; Habel, J.C., eds. Biodiversity hotspots distribution and protection of conservation priority areas. Springer, Heidelberg, Germany. https://doi.org/10.1007/978-3-642-20992-5
National Institute of Standards and Technology - NIST. 2012. Standard Reference Materials - SRM 2709, 2710 and 2711 Addendum Issue Date: 18 January 2002. https://www.nist.gov/ srm

Nesbitt, H.W.; Young, G.M. 1982. Early Proterozoic climates and plate motions inferred from major element chemistry of lutites. Nature 299: 715-717. https://doi. org/10.1038/299715a0

Nogueira, T.A.R.; Abreu Junior, C.H.; Alleoni, L.R.F.; He, Z.; Soares, M.R.; Vieira, C.S.; Lessa, L.G.F.; Capra, G.F. 2018. Background concentrations and quality reference values for some potentially toxic elements in soils of São Paulo state, Brazil. Journal of Environmental Management 221: 10-19. https://doi.org/10.1016/j.jenvman.2018.05.048

Oliveira, C.V.; Moura, C.A.V. 2019. Provenance of detrital zircons of the canindé group (Parnaíba Basin), northeastern Brazil. Journal of South American Earth Sciences 90: 162-180. https:// doi.org/10.1016/j.jsames.2018.12.009

Oliveira, G.J.G.; Vasconcelos, M.A.R.; Crósta, A.P.; Reimold, W.U.; Góes, A.M.; Kowitz, A. 2014. Shatter cones and planar deformation features confirm Santa Marta in Piauí state, Brazil, as an impact structure. Meteoritics and Planetary Science 49: 1915-1928. https://doi.org/10.1111/maps. 12368

Omodara, L.; Pitkäaho, S.; Turpeinen, E.; Saavalainen, P.; Oravisjärvi, K.; Keisk, R. 2019. Recycling and substitution of light rare earth elements, cerium, lanthanum, neodymium, and praseodymium from end-of-life applications: a review. Journal of Cleaner Production 236: 117573. https://doi.org/10.1016/j. jclepro.2019.07.048

Pagano, G.; Thomas, P.; Nunzio, A.; Trifuoggi, M. 2019. Human exposures to rare earth elements: present knowledge and research prospects. Environmental Research 171: 493-500. https://doi.org/10.1016/j.envres.2019.02.004

Paye, H.S.; Melo, J.W.V.; Mascarenhas, G.R.L.G.; Gasparon, M. 2016. Distribution and fractionation of the rare earth elements in Brazilian soils. Journal of Geochemical Exploration 161: 2741. https://doi.org/10.1016/j.gexplo.2015.09.003

Pfaltzgraff, P.A.S.; Torres, F.S.M.; Brandão, R.L. 2010. Geodiversity of the State of Piauí = Geodiversidade do Estado do Piauí. Companhia de Pesquisa de Recursos Minerais, Brasília, DF, Brazil (in Portuguese).

Preston, W.; Nascimento, C.W.A.; Biondi, C.M.; Souza Junior, V.S.; Silva, W.R.; Ferreira, H.A. 2014. Quality reference values for heavy metals in soils of the Rio Grande do Norte. Revista Brasileira de Ciência do Solo 38: 1028-1037 (in Portuguese, with abstract in English). http://dx.doi.org/10.1590/S010006832014000300035

Ramos, S.J.; Dinalli, G.S.; Carvalho, T.S.; Chaves, L.C.; Siqueira. J.O.; Guilherme, L.R.G. 2016. Rare earth elements in raw materials and products of the phosphate fertilizer industry in South America: Content, signature, and crystalline phases. Journal of Geochemical Exploration 168: 177-186. https://doi. org/10.1016/j.gexplo.2016.06.009

Rao, C.R.; Sahuquillo, A.; Lopez-Sanchez, J.F. 2010. Comparison of single and sequential extraction procedures for the study of rare earth elements remobilisation in different types of soils. Analytica Chimica Acta 662: 128-136. https://doi.org/10.1016/j. aca.2010.01.006 
Sadeghi, M.; Morris, G.A.; Carranza, E.J.M.; Ladenberger, A.; Andersson, M. 2013. Rare earth element distribution and mineralization in Sweden: an application of principal component analysis to FOREGS soil geochemistry. Journal of Geochemical Exploration 133: 160-175. https://doi. org/10.1016/j.gexplo.2012.10.015

Santos, S.N.; Alleoni, L.R.F. 2013. Reference values for heavy metals in soils of the Brazilian agricultural frontier in southwestern Amazônia. Environmental Monitoring and Assessment 185: 5737-5748. https://doi.org/10.1007/s10661012-2980-7

Santos, H.G.; Jacomine, P.K.T.; Anjos, L.H.; Oliveira, V.A.; Lumbreras, J.F.; Coelho, M.R.; Almeida, J.A.; Araújo Filho, J.C.; Oliveira, J.B.; Cunha, T.J.F. 2018. Brazilian Soil Classification System. 5ed. Embrapa Solos, Brasília, DF, Brazil.

Santos, J.C.B.; Pera, E.L.; Oliveira, C.S.; Souza Júnior, V.S.; Pedron, F.A.; Corrêa, M.M.; Azevedo, A.C. 2019. Impact of weathering on REE distribution in soil-saprolite profiles developed on orthogneisses in Borborema Province, NE Brazil. Geoderma 347: 103-117. https://doi.org/10.1016/j.geoderma.2019.03.040

Silva, Y.J.A.B.; Nascimento, C.W.A.; Silva, Y.J.A.B.; Biondi, C.M.; Silva, C.M.C.A.C. 2016. Rare earth element concentrations in brazilian benchmark soils. Revista Brasileira de Ciência do Solo 40: 1-13. http://dx.doi.org/10.1590/18069657rbcs20150413

Silva, C.M.C.A.C.; Barbosa, R.S.; Nascimento, C.W.A.; Silva, Y.J.A.B. 2018a. Geochemistry and spatial variability of rare earth elements in soils under different geological and climate patterns of the Brazilian northeast. Revista Brasileira de Ciência do Solo 42: e0170342. https://doi.org/10.1590/180696 $57 \mathrm{rbcs} 20170342$

Silva, Y.J.A.B.; Nascimento, C.W.A.; Biondi, C.M.; Straaten, P.V.; Silva, Y.J.A.B. 2018b. Rare earth element geochemistry during weathering of S-type granites from dry to humid climates of Brazil. Journal of Plant Nutrition and Soil Science 181: 938953. https://doi.org/10.1002/jpln.201700440

Silva, F.B.V.; Nascimento, C.W.A.; Alvarez, A.M.; Araújo, P.R.M. 2019. Inputs of rare earth elements in Brazilian agricultural soils via P-containing fertilizers and soil correctives. Journal of Environmental Management 232: 90-96. doi: 10.1016/j. jenvman.2018.11.031
Souza, D.F.; Barbosa, R.S.; Silva, Y.J.A.B.; Moura, M.C.S.; Oliveira, R.P.; Martins, V. 2019. Genesis of sandstone-derived soils in the Cerrado of the Piauí state, Brazil. Ambiente \& Água 14: e2355. https://doi.org/10.4136/ambi-agua.2355

Taylor, S.R.; McLennan, S.M. 1985. The Continental Crust: Its Composition and Evolution; An Examination of the Geochemical Record Preserved in Sedimentary Rocks. Blackwell, Oxford, UK.

Tyler, G. 2004. Rare earth elements in soil and plant systems: a review. Plant and Soil 267: 191-206. https://doi.org/10.1007/ s11104-005-4888-2

United States Environmental Protection Agency [USEPA]. 1998. Method 3051a: microwave assisted acid digestion of sediments, sludges, soils, and oils. https://www.epa.gov/sites/production/ files/2015-12/documents/3051a.pdf [Accessed Jan 20, 2020]

Vermeire, M.L.; Cornu, S.; Fekiacova, Z.; Detienne, M.; Delvaux, B.; Cornélis, J.T. 2016. Rare earth elements dynamics along pedogenesis in a chronosequence of podzolic soils. Chemical Geology 446: 163-174. https://doi.org/doi: 10.1016/j. chemgeo.2016.06.008

Wang, L.; Liang, T. 2016. Anomalous abundance and redistribution patterns of rare earth elements in soils of a mining area in Inner Mongolia, China. Environmental Science and Pollution Research 23: 11228-11330. https://doi.org/10.1007/s11356-0166351-8

Wei, F.; Zheng, C.; Chen, J.; Wu, Y. 1991. Study on the background contents on 61 elements of soils in China. Environmental Science 12: 12-19.

Yeomans, J.C.; Bremmer, J.M. 1988. A rapid and precise method for routine determination of organic carbon in soil. Communications in Soil Science and Plant Nutrition 19: 14671476. https://doi.org/10.1080/00103628809368027

Yoshida, S.; Muramatsu, Y.; Tagami, K.; Uchida, S. 1998. Concentrations of lanthanide elements, $\mathrm{Th}$, and $\mathrm{U}$ in 77 Japanese surface soils. Environment International 24: 275-286. https://doi.org/10.1016/S0160-4120(98)00006-3 